\title{
The Gelasian Stage (Upper Pliocene): A new unit of the global standard chronostratigraphic scale
}

\author{
1 Department of Geology, Paleontology and Geophysics, University of Padova, Italy \\ 2 Department of Geology and Geodesy, University of Palermo, Italy \\ 3 AGIP, Laboratori Bolgiano, via Maritano 26, 20097 San Donato M., Italy
}

\begin{abstract}
The Gelasian has been formally accepted as third (and uppermost) subdivision of the Pliocene Series, thus representing the Upper Pliocene. The Global Standard Stratotype-section and Point for the Gelasian is located in the Monte S. Nicola section (near Gela, Sicily, Italy).
\end{abstract}

\section{Introduction}

This short report announces the formal ratification of the Gelasian Stage as the uppermost subdivision of the Pliocene Series, which is now subdivided into three stages (Lower, Middle, and Upper). Furthermore, the Global Standard Stratotype-section and Point (GSSP) of the Gelasian is briefly presented and discussed. More information is contained in the paper by Rio et al. (1994), proposing the new chronostratigraphic unit, on which the formal procedure for ratification was based.

A postal ballot on the proposal by Rio et al. (1994) was forwarded to all voting members of the Subcommission on Neogene Stratigraphy (SNS) in 1995 and accepted by a large majority (about $80 \%$ ). Following the results of the postal ballot, a formal recommendation of SNS was submitted to the International Commission on Stratigraphy (ICS) in March 1996. Official acceptance by ICS and ratification by the Executive Committee of IUGS were achieved at the 30th International Geological Congress in Beijing (August 1996).

\section{Background and motivation}

It is far beyond the scope of this report to review the development of Pliocene chronostratigraphy over the last century. The reader may find more information on the subject in Berggren (1971), Berggren \& Van Couvering (1974), Cita (1975a) and Rio et al. (1991).

Even if numerous stages have been proposed over the years for subdividing the 3.5 Ma long Pliocene Series (Astian, Piacenzian, Zanclean, Fossanian, etc.), a two-folded subdivision into a Zanclean (Lower Pliocene) and Piacenzian (Upper Pliocene) Stages became well established in the eighties (e.g. Berggren et al., 1985; Haq and Van Eysinga, 1987).

Subsequently, a great effort was devoted to frame the chronostratigraphic units of the Pliocene within the increasingly more detailed biomagnetostratigraphy recently developed in the Mediterranean area (e.g. Rio et al., 1990; Sprovieri, 1992, 1993; Hilgen, 1991a, b, among many others). This approach led Rio et al. (1991, 1994) to demonstrate that none of the previously proposed Pliocene standard stages actually covered the interval of time between the top of the Piacenzian historical stratotype in Castell'Arquato (Northern Italy) and the Pliocene-Pleistocene boundary at Vrica (Southern Italy; Aguirre \& Pasini, 1985).
Of course, this consideration alone does not imply that a new stage should be defined to represent the discovered gap. However, the top of the Piacenzian stratotype falls in a critical point of the evolution of Earth climatic system (i.e. close to the final build-up of the Northern Hemisphere Glaciation), which is characterized by plenty of signals (magnetostratigraphic, biostratigraphic, etc; see further on) with a worldwide correlation potential. Therefore, Rio et al. $(1991,1994)$ argued against the practice of extending the Piacenzian Stage up to the Pliocene-Pleistocene boundary and proposed the introduction of a new stage (initially "unnamed" in Rio et al., 1991), the Gelasian, in the Global Standard Chronostratigraphic Scale.

\section{The Gelasian Stage}

As commented previously, a new chronostratigraphic unit is proposed to represent the interval of time above the Piacenzian historical stratotype and up to the already ratified GSSP of the Pleistocene Series.

The rank proposed is that of Stage which, according to the International Stratigraphic Guide (Salvador, 1994), is the "basic working unit of chronostratigraphy"; in addition "it is the smallest unit... that can be recognized at a global scale", a condition perfectly matched by the proposed Stage (see below).

The name Gelasian is derived by the Greek name of the town of Gela (Southern Sicily), close to the boundary stratotype-section.

It is probably worth mentioning that the yellowish sandy sediments outcropping above the Piacenzian stratotype section in Castell' Arquato and below the local appearance of Artica islandica, that is a stratigraphic interval correlatable with the Gelasian, were ascribed to the Astian by Pareto (1865); however, the Astian, whose type is located in the Piedmont region (Northern Italy) (Mayer, 1868; Ferrero, 1971), has been abandoned, being represented by shallow water sandy facies, most probably Early or Middle Pliocene in age (Sampò et al., 1968).

In the literature, some regional chronostratigraphic units (mainly regional stages) probably correlatable to (part of) the Gelasian Stage are found. For instance, the marine Nukumaruan Stage (Edwards, 1987) in New Zealand, the continental Tiglian stage (Zagwijn, 1974) in Northwestern Europe, and the continental "Middle Villafranchian" (Masini \& Torre, 1990) in the Mediterranean.

\section{The GSSP of the Gelasian Stage}

In this paragraph, we will briefly illustrate the characteristics of the Monte San Nicola section (Sicily), the definition of the "golden spike", and the various stratigraphic tools that provide an excellent potential for precise approximation of the boundary all over the world, in different geologic and stratigraphic settings. A more exhaustive account can be found in Rio et al. (1994). 


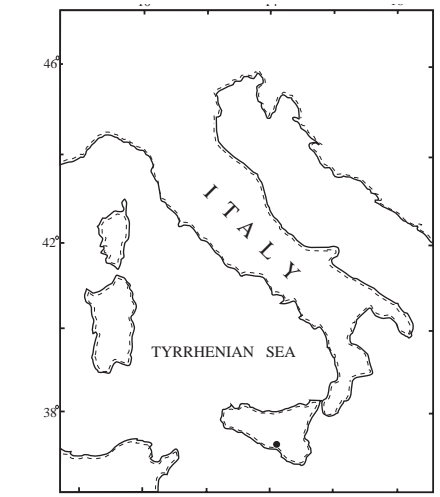

Figure 1

Location of the

Monte San

Nicola section,

the GSSP of the

Gelasian Stage

(modified after

Rio et al., 1994).
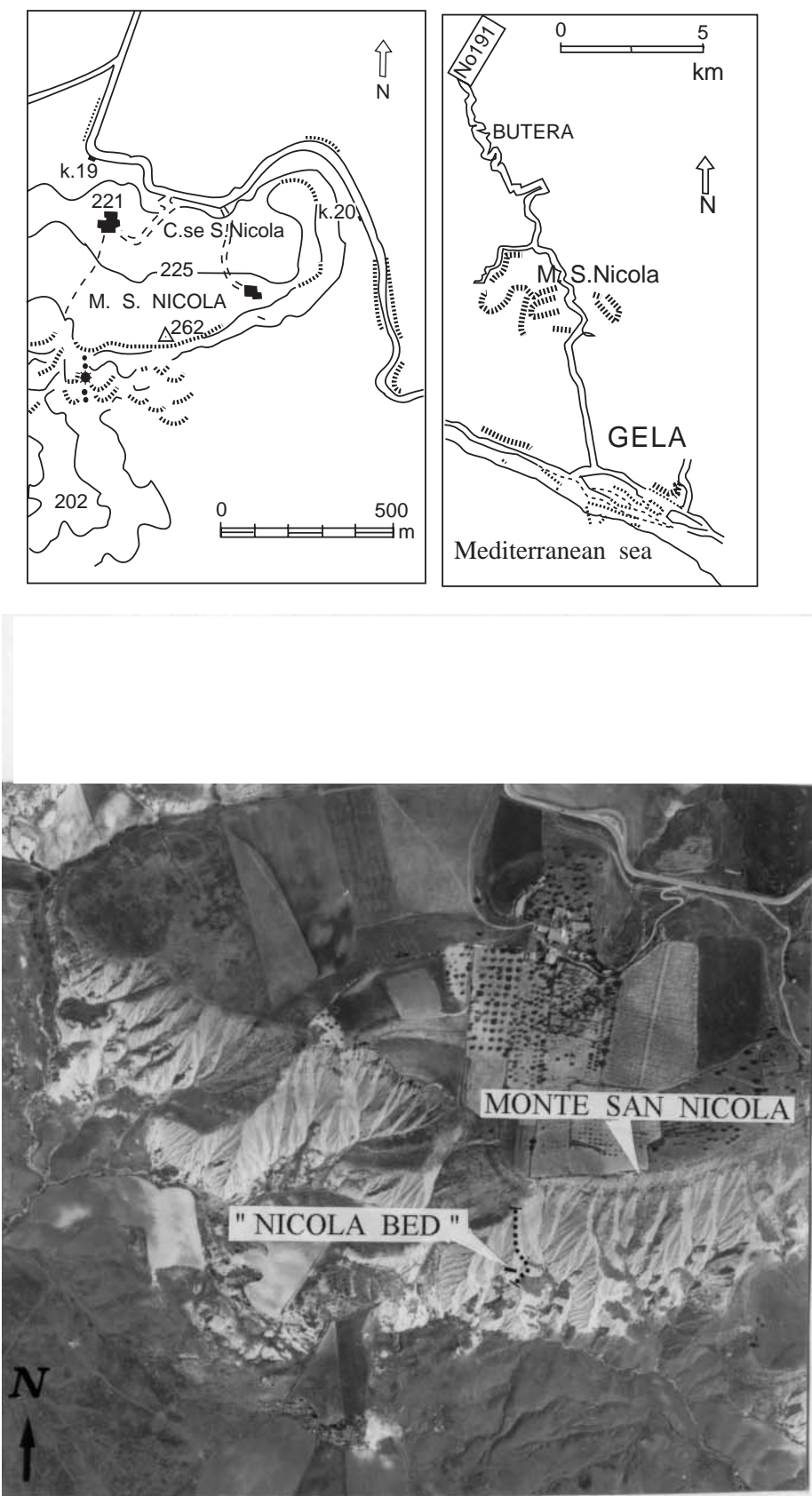

Figure 2 Pictures of the Gelasian Stratotype section. In the lower right side, the arrow indicates the base of the marly layer overlying sapropel MPRS.
It is worth mentioning that another section was considered as candidate for the location of the base of the Gelasian Stage, that is the Singa section (Calabria, Southern Italy). Both sections have been thoroughly studied and well constrained in time (Channell et al., 1992; Sprovieri, 1992, 1993; Zijderveld et al., 1991; Lourens et al., 1992), but outcropping and accessibility conditions are better at Monte San Nicola, that was thus preferred.

\section{The section}

\section{Location}

The section outcrops in the badlands ("calanchi") on the southern slope of the Monte San Nicola, some $10 \mathrm{~km}$ to the N-NW of the town of Gela (Caltanissetta province, Sicily) (Figure 1 and 2). The area is represented on the Carta Topografica d'Italia at 1:25000 Foglio 272, II NO (Ponte Olivo). The section can be reached, also by car, following a path which starts from the main road 191 between $\mathrm{km} 19$ and 20 and leads to an old, little farm from which, crossing a small field by feet, the top of the section is easily reached.

\section{The stratigraphic succession}

The $161 \mathrm{~m}$ of the Plio-Pleistocene succession of the Monte San Nicola section were deposited on a piggy-back basin located on the so-called Gela Nappe (Argnani, 1987). They rest on sediments of the Numidian Flysch Formation (Oligocene-Lower Miocene; Gela Nappe). The Plio-Pleistocene strata dip 5-10 ${ }^{\circ}$ to the $\mathrm{E}$ and are unaffected by tectonic disturbances in the critical interval for the definition of the boundary. The depositional environment, at least for the boundary interval, is inferred to be a slope-basin setting with a water depth ranging from 500 to $1000 \mathrm{~m}$ (Rio et al., 1994, and references therein).

The lower $36 \mathrm{~m}$ are constituted by rhythmically bedded marls and limestones of the Trubi Formation (Cita and Gartner, 1973),
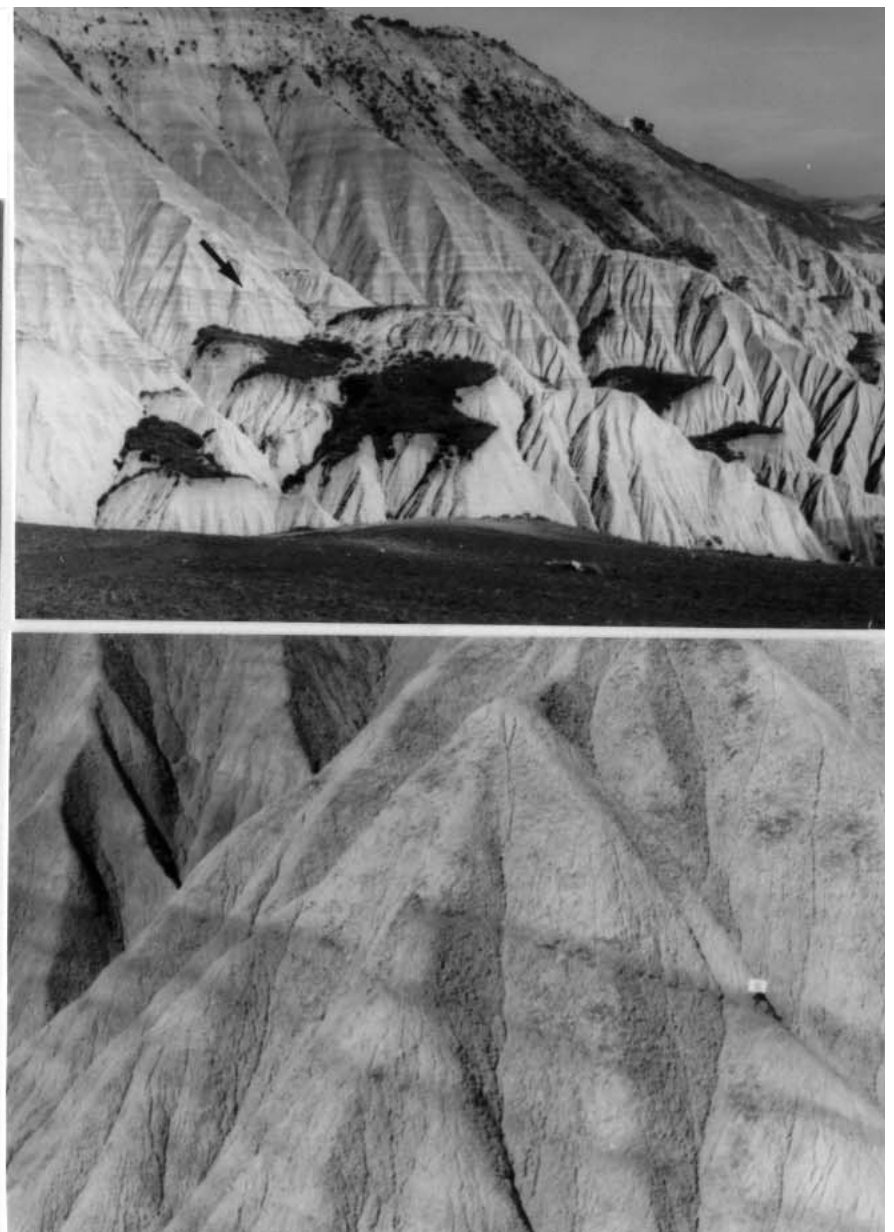
transitionally grading upward into the marly-silty Monte Narbone Formation. The latter is characterized by brownish-red laminated intervals ("sapropels" of Hilgen, 1991a, b and Lourens et al., 1992) and by brownish non-laminated manganesiferous levels. Both are important for regional correlations; the "sapropels" have been demonstrated by Hilgen (1991a, b) to be an important tool for astronomical calibration of the Mediterranean sedimentary record.

The section was first described by Spaak (1983) who studied the planktonic foraminifers. Other studies are those by Bonaduce \& Sprovieri (1984) (ostracodes), Driever (1988) (calcareous nannofossils), Channell et al. (1992) (biomagnetostratigraphy and paleoclimatology). Paleoenvironmental and cyclostratigraphic aspects of the section are dealt with in Sprovieri et al. (1986), Bertoldi et al. (1989), and Sprovieri $(1992,1993)$.

Biomagnetostratigraphy, faunistic curve, sapropel stratigraphy

In the last years, the development of an integrated biostratigraphy (nannofossils and foraminifers), magnetostratigraphy and precise lithostratigraphy/cyclostratigraphy of the rhythmically bedded sedimentary succession widely outcropping in Sicily and Calabria has resulted in an unprecedented time framework for the Mediterranean Pliocene and Pleistocene (among many others, Rio et al., 1990; Sprovieri, 1992, 1993; Hilgen, 1987, 1991a, b; Zijderveld et al., 1991; Lourens et al., 1992, 1996). This framework permits a precise bed-by-bed correlation of stratigraphic sections even tens or hundreds of kilometers apart, proving or disproving stratigraphic continuity of specific intervals. Besides, it allows a calibration of every single limestone-marl or marl-sapropel couplets of the entire sedimentary record to specific features in the curve of the quasi-periodic oscillations of the Earth's orbital parameters (Hilgen, 1991a, b; Lourens et al., 1996), leading to very precise (few kyrs) astronomical calibration of bioevents, magnetic boundaries and lithological record.

Concerning nannofossil biostratigraphy, the Monte San Nicola section is extended from Zone MNN14-15 to the top of Zone MNN19b (Rio et al., 1990), from Zone NN15 to NN19 (Martini, 1971), and from Zone CN11b to CN13a (Okada and Bukry, 1980). Concerning planktonic foraminifers, the section is extended from
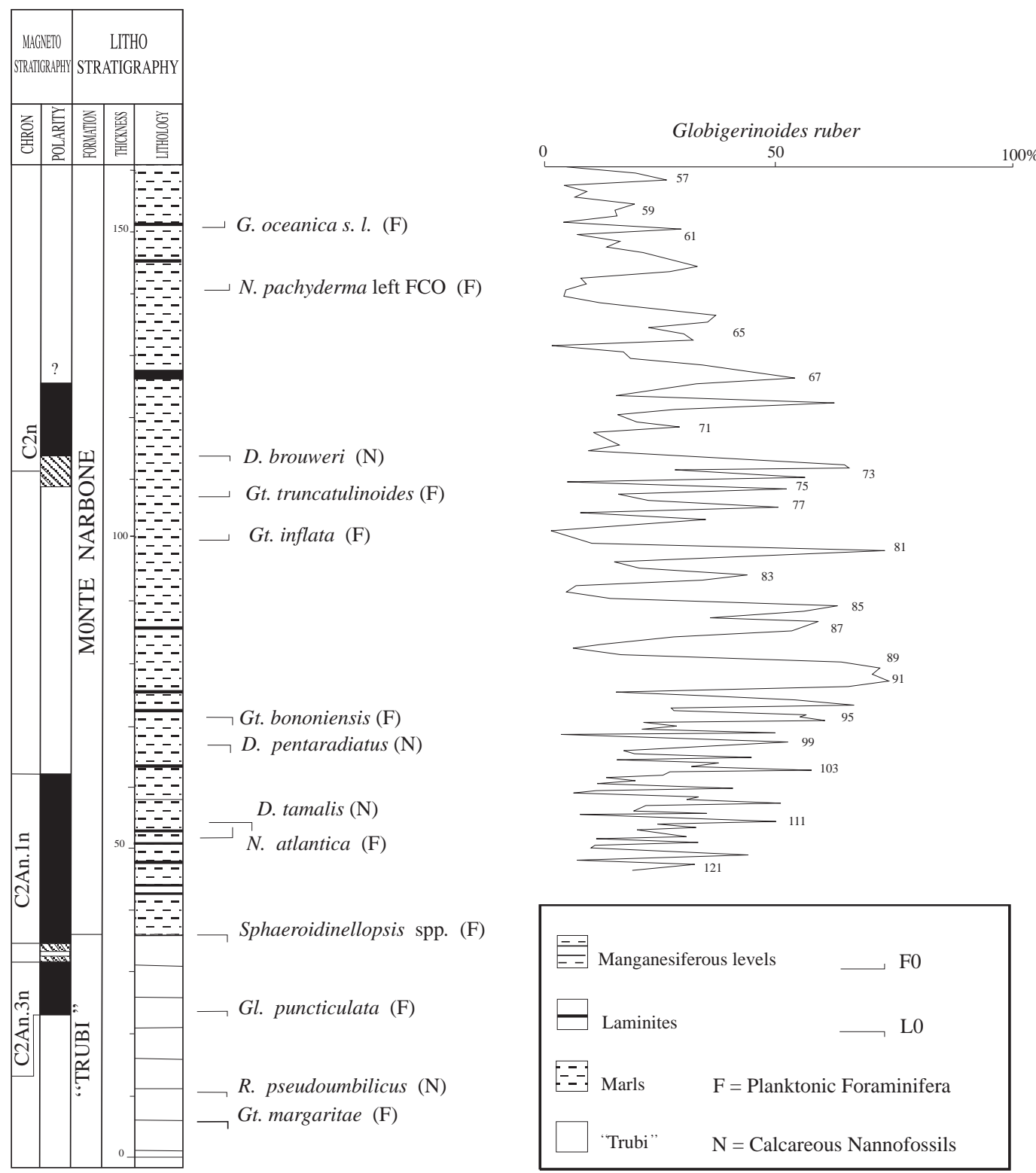

Figure 3 Summary of main magnetostratigraphic and biostratigraphic data available for the Monte San Nicola section. On the right side, the abundance fluctuations of Globigerinoides ruber, a surrogate for recognizing oxygen isotope stages (see text for further explanation) (after Rio et al., 1994). 


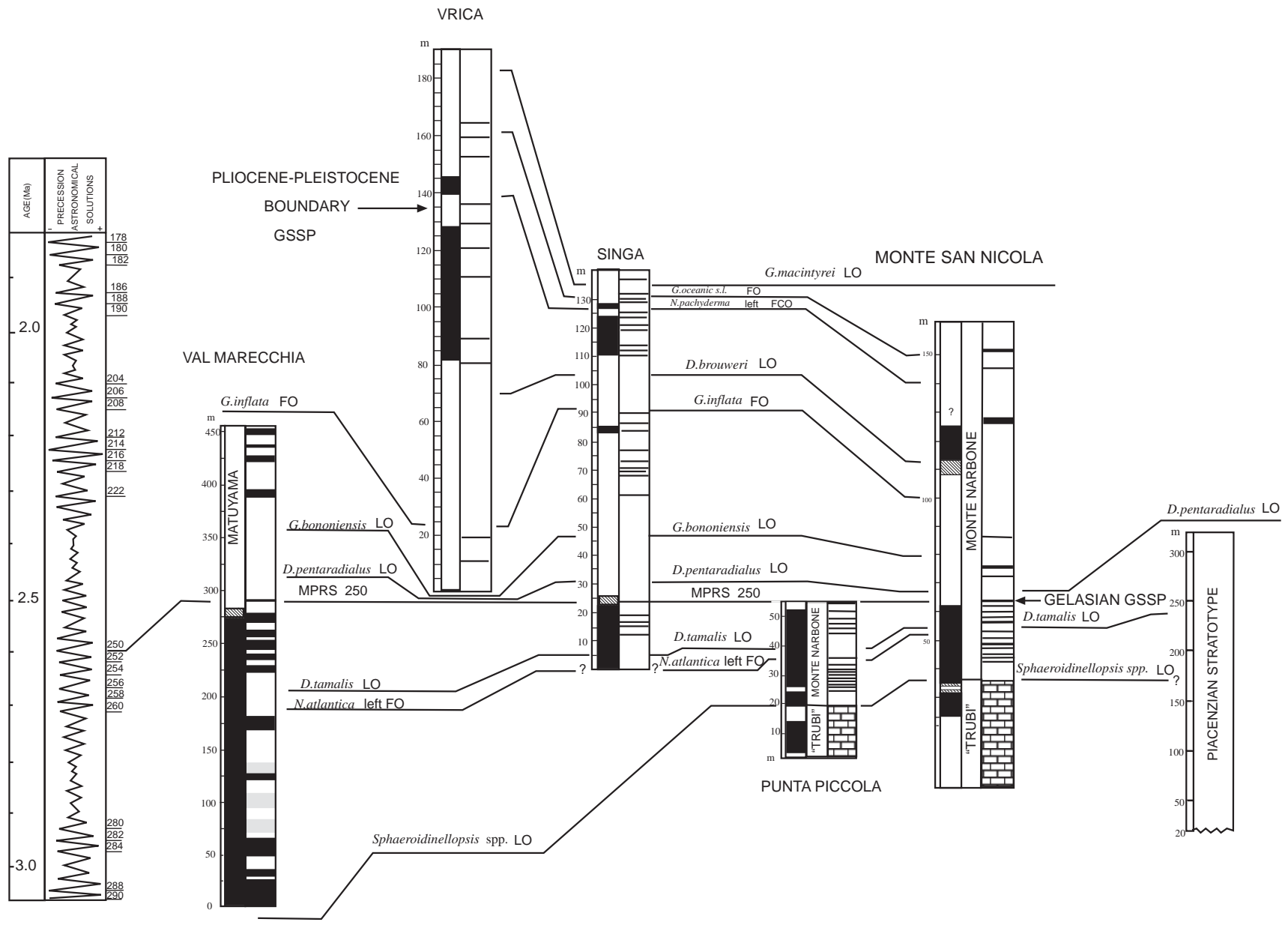

Figure 4 Correlation of different stratigraphic sections across the Piacenzian/Gelasian boundary from Northern Italy, to Calabria and Sicily, showing the high correlation potential of this chronostratigraphic boundary (after Rio et al., 1994).

Zone MP13 to the Globigerina cariacoensis Zone (Cita, 1973, 1975b, emended by Sprovieri, 1992), and from Zone N19 to N21 (Blow, 1969) (Figure 3).

From a magnetostratigraphic point of view, the section spans the interval from the upper part of the Gilbert Chron (C2Ar of Cande $\&$ Kent, 1992, 1995) to the Matuyama Chron above the Olduvai Subchron (C1r). The Gauss/Matuyama boundary is clearly detectable and precisely located (Channell et al., 1992) (Figure 3).

Abundance fluctuations of Globigerinoides ruber, a surrogate for recognizing oxygen isotopic stages (Sprovieri, 1993; see also Ruddimann et al., 1989, Lourens et al., 1992), allow the recognition in the Monte San Nicola section of all isotopic stages from 116 to 56 of Raymo et al. (1989) (Figure 3).

In the interval critical for the definition of the base of the Gelasian Stage, a cluster of six sapropels or manganesiferous levels is recognized and correlated to coeval sections in Sicily (Punta Piccola), Calabria (Singa) and even Northern Italy (Val Marecchia). The single sapropels of this cluster (cluster "A" of Verhallen, 1987) have been coded by Hilgen (1991b) as Mediterranean Precession Related Sapropels (MPRS) and tightly linked, as already discussed, to the corresponding precessional cycle. One of this sapropel is selected as lithologic marker for the location of the "golden spike" (see below).

Based on all the evidences listed above, it can be confidently assumed that the Monte San Nicola section is remarkably complete in a thick stratigraphic interval straddling the selected boundary.

\section{The boundary ("golden spike")}

\section{Definition and age}

The base of the marly layer overlying sapropel MPRS 250, located at $62 \mathrm{~m}$ in the Monte San Nicola section, is the defined base of the Gelasian Stage (Middle Pliocene-Upper Pliocene boundary) (Figure 3 and Figure 4, right side).

The astrochronological age of sapropel MPRS 250 (mid-point), corresponding to precessional cycle 250 from the present, is 2.588 Ma (Lourens et al., 1996), which can be assumed as the age of the boundary.

\section{Correlation tools}

The base of the Gelasian corresponds to isotopic stage 103 of Raymo et al. (1989), predating by about $60 \mathrm{kyrs}$ the prominent cold stage 100 , often referred to as final build-up of Northern Hemisphere Glaciation. This major climatic threshold is also witnessed by increase in ice rafted detritus in northern latitude oceanic sediments (Raymo et al., 1989), change in vegetation distribution patterns (Tiglian-Pretiglian boundary of Zagwijn, 1974; Arquatian phase of Lona, 1962), the beginning of loess sedimentation in China (Kukla $\&$ An, 1989) and migratory events in the continental vertebrate fauna (the elephant-Equus event in the Eurasian region; Lindsay et al., 1980; Azzaroli et al., 1988 and references therein).

The Gauss/Matuyama boundary, located about $1 \mathrm{~m}$ (20 kyrs) below the "golden spike", is a very good approximation of the base of the Gelasian outside the stratotype section. 
From a biostratigraphic point of view, the extinction level (LO) of the nannofossils Discoaster pentaradiatus and D. surculus occur in most low- and mid-latitude areas close to isotopic stages 99, that is some 80 kyrs above the boundary. In the Mediterranean and North Atlantic the LO of the foraminifer Globorotalia bononiensis (or $G$. puncticulata of some authors) is recorded in stage 96, i.e. some 140 kyrs above the boundary. The LO of the radiolaria Stichocorys peregrina, coincident with the base of the Pterocanium prismaticum Zone, approximates the Gauss-Matuyama boundary (Sanfilippo et al., 1985). The first occurrence of the diatom Nitzschia joussaea in low-latitudes and the LO of Denticulopsis kamtschatica in the North Pacific mid- and high-latitudes approximate the Gauss-Matuyama boundary (Barron, 1985).

\section{Conclusion}

The introduction of the Gelasian Stage (Upper Pliocene) and the formal definition of its base mark an important step towards the compilation of the Global Standard Chronostratigraphic Scale of the Neogene, which now include a three-folded Pliocene Series. In this issue, we also report on the acceptance and ratification of the base of the underlying Piacenzian Stage (Middle Pliocene).

The definition of the base of the Zanclean Stage (Lower Pliocene) is one of the major goals of SNS in the next few months: we hope to report on this important achievement soon.

\section{References}

Aguirre, E, and Pasini, G, 1985, The Pliocene-Pleistocene Boundary: Episodes, v. 8, pp. 116-120.

Argnani, A, 1987, The Gela nappe: evidence of accretionary melange in the Maghrebian foredeep of Sicily: Mem. Soc. Geol. It., v. 38, pp. 419-428.

Azzaroli, A, De Giuli, C, Ficcarelli, G, and Torre, D, 1988, Late Pliocene to Early Pleistocene Mammal in Eurasia: faunal succession and dispersal event: Palaeogeogr. Palaeoclim. Palaeoecol., v. 66, pp. 77-100.

Barron, J A, 1985, Miocene to Holocene planktic diatoms, in Bolli, H M, Saunders, J B e Perch-Nielsen, K (eds.): Plankton Stratigraphy, pp. 763-809.

Berggren, W A, and Van Couvering, J A, 1974, The late Neogene: Palaeogeogr. Palaeoclim. Palaeoecol., v. 16, pp. 1-215.

Berggren, W A, 1971, Tertiary boundaries and correlations, in Funnell R.M.S. and Riedel W.R. (eds.), The Micropaleontology of oceans: Cambridge Univ. Press, pp. 693-809.

Berggren, W A, Kent, D V, and Van Couvering, J A, 1985, The Neogene: Part 2. Neogene geochronology and chronostratigraphy, in Snelling, N J (ed.), Geochronology and the Geologic Record: Geol. Soc. (London) Spec. Pap., pp. 211-260.

Berggren, W A, Kent, D V, Swisher III, C C, and Aubry, M-P, 1995, A Revised Cenozoic Geochronology and Chronostratigraphy, in Berggren, W A, Kent, D V, and Hardenbol, J (eds.), Geochronology, Time Scales and Global Stratigraphic Correlations: A Unified Temporal Framework for an Historical Geology: SEPM Spec. Publ. 54, pp. 129-212.

Bertoldi, R, Rio, D, and Thunell, R, 1989, Pliocene-Pleistocene vegetational and climatic evolution of the south-central Mediterranean: Palaeogeogr. Palaeoclim. Palaeoecol., v. 72, pp. 263-275.

Blow, W H, 1969, Late Middle Eocene to Recent planktonic foraminiferal biostratigraphy: Proc. I Intern. Conf. Plankt. Microf., Geneva 1967, v. 1, pp. 199-421.

Bonaduce, G, and Sprovieri, R, 1984, The appearance of Cyteropteron testudo Sars (Crustacea: Ostracoda) is a Pliocene event. Evidence from a Sicilian sequence (Italy): Boll. Soc. Paleont. It., v. 23, pp. 131-136.

Cande, S C, and Kent, D V, 1992, A New Geomagnetic Polarity Time Scale for the Late Cretaceous and Cenozoic: Journ. Geophys. Research, v. 97, pp. 13,917-13,951.

Cande, S C, and Kent, D V, 1995, Revised calibration of the geomagnetic polarity time scale for the late Cretaceous and Cenozoic: Journ. Geophys. Res., v. 100: 6093-6095.

Channell, J, Di Stefano, E, and Sprovieri, R, 1992, Calcareous Plankton Biostratigraphy, Magnetostratigraphy and Paleoclimatic History of the PlioPleistocene Monte San Nicola Section (Southern Sicily), Boll. Soc. Paleont. It., v. 31, pp. 351-382.
Cita, M B, and Gartner, S, 1973, Studi sul Pliocene e sugli strati di passaggio dal Miocene al Pliocene. IV. The stratotype Zanclean, foraminiferal and nannofossil biostratigraphy: Riv. It. Paleont. Strat., v. 79, pp. 503-558.

Cita, M B, 1973, Pliocene stratigraphy and chronostratigraphy, in: Ryan, W.B.F., Hsu, K.J., et al., Init. Rep. of the DSDP, v. 13, pp. 1343-1379.

Cita, M B, 1975a, The Miocene/Pliocene boundary: History and definition, in Saito, T. and Burckle, L.H. (eds.), Late Neogene Epoch Boundaries: New York, Micropaleontology Press, Spec. Publ. 1, pp. 1-30.

Cita, M B, 1975b, Studi sul Pliocene e sugli strati di passaggio dal Miocene al Pliocene. VII. Planktonic foraminiferal biozonation of the Mediterranean Pliocene deep sea record. A revision: Riv. It. Paleont. Strat., v. 81, pp. 527-544.

Driever, B W M, 1988. Calcareous nannofossil biostratigraphy and paleoenvironmental interpretation of the Mediterranean Pliocene: Utrecht Micropaleontol. Bull., v. 36, 245 pp.

Edwards, A R, 1987, An integrated biostratigraphy, magnetostratigraphy and oxygen isotope stratigraphy for the late Neogene of New Zealand: New Zealan Geol. Surv., 76 pp.

Ferrero, E, 1971, Astian, in Carloni G et al. (eds.), Stratotypes of Mediterranean Neogene Stages: Giorn. Geol., v. 37, pp. 33-40.

Haq, B U , and Van Eysinga, W M, 1987, Geological Time Table: Elsevier Sc. Publ B. U.

Hilgen, F J, 1987, Sedimentary rhithms and high-resolution chronostratigraphic correlations in the Mediterranean Pliocene: Newsl. Stratigr., v. 17, pp. 109-127.

Hilgen, F J, 1991a, Astronomical calibration of Gauss to Matuyama sapropels in the Mediterranean and implication for the Geomagnetic Polarity Time Scale: Earth and Planet. Sci. Lett., v. 104, pp. 226-244.

Hilgen, F J, 1991b, Extension of the astronomically calibrated (polarity) time scale to the Miocene/Pliocene boundary: Earth and Planet. Sci. Lett., v. 107 , pp. 349-368.

Kukla G, and An, Z, 1989, Loess stratigraphy in central China: Palaeogeogr. Palaeclim. Palaeoecol., v. 72, pp. 203-225.

Lindsay, E H, Opdyke, N D, and Johnson, N M, 1980, Pliocene dispersal of the horse Equus and late Cenozoic mammalian dispersal event: Nature, v. 287, pp. $135-138$.

Lona, F, 1962, Prime analisi pollinologiche sui depositi terziari-quaternari di Castell'Arquato; reperti di vegetazione da clima freddo sotto le formazioni calcaree a Amphistegina: Boll. Soc. Geol. It., v. 81, pp. 89-91.

Lourens, L J, Antonarakou, A, Hilgen, F J, Van Hoof, A A M, VergnaudGrazzini, C, and Zachariasse, W J, 1996, Evaluation of the Plio-Pleistocene atronomical timescale: Paleoceanography, v. 11, pp. 391-413.

Lourens, L J, Hilgen, F J, Gudjonsson, L, and Zachariasse, W J, 1992, Late Pliocene to early Pleistocene astronomically forced sea surface productivity and temperature variations in the Mediterranean: Mar. Micropaleontol., v. 19, pp. 49-78.

Martini, E, 1971, Standard Tertiary and Quaternary calcareous nannoplankton zonation, in Farinacci, A (ed.), Proc. II Planktonic Conference, Roma 1970, pp. 739-785.

Masini, F, and Torre, D, 1990, Large Mammal dispersal events at the beginning of the Late Villafranchian, in Lindsay, E H et al. (eds.), European Neogen Mammal Chronology: Plenum Press, pp. 131-138.

Mayer, C, 1868, Tableau synchronistique des terraines tertiaires supÈrieurs: IV Ed., Manz, Zurich.

Okada, H, and Bukry, D, 1980, Supplementary modification and introduction of code numbers to the low-latitude coccolith biostratigraphic zonation (Bukry, 1973; 1975): Mar. Micropaleontol., v. 5, pp. 321-325.

Pareto, M, 1865, Sur les subdivisions que l'on pourrait Ėtablir dand les terraines Tertiaires de l'Apennin septentrional: Bull. Soc. Geol. France, v. 22, pp. 210-277.

Raymo, M E, Ruddiman, W F, Backman, J, Clement, B M, and Martinson, D G, 1989, Late Pliocene variation in northern hemisphere ice sheets and North Atlantic Deep Water circulation: Paleoceanography, v. 4, pp. 413-446.

Rio, D, Raffi, I, and Villa, G, 1990, Pliocene-Pleistocene calcareous nannofossils distribution patterns in the Western Mediterranean, in Kastens, $\mathrm{K}$ A, Mascle, J, et al., Proc. ODP, Sci. Results, v. 107, pp. 513-533.

Rio, D, Sprovieri, R, and Di Stefano, E, 1994, The Gelasian Stage: a proposal of a new chronostratigraphic unit of the Pliocene Series: Riv. It. Paleont. Strat., v. 100 , pp. 103-124.

Rio, D, Sprovieri, R, and Thunell, R, 1991, Pliocene-lower Pleistocene chronostratigraphy: A re-evaluation of Mediterranean type sections: Geol. Soc. Am. Bull., v. 103, pp. 1049-1058.

Ruddiman, W F, Raymo, M E, Martinson, D G, Clement, B M, and Backman, J, 1989, Pleistocene evolution: northern hemisphere ice sheets and North Atlantic Ocean: Paleoceanogr., v. 4, pp. 353-412. 
Salvador, A (Ed.), 1994, International Stratigraphic Guide. A guide to stratigraphic classification, terminology, and procedure. Second Edition.

SampÚ, M, Zappi, L, and Caretto, P G, 1968, Les ForaminifËres de l'Astien: Giorn. Geol., v. 35, pp. 277-293.

Sanfilippo, A, Westberg-Smith, M J, and Riedel, W R, 1985. Cenozoic radiolaria, in Bolli, H M, Saunders, J B e Perch-Nielsen, K (eds.), Plankton Stratigraphy, pp. 631-712.

Spaak, P, 1983, Accuracy in correlation and ecological aspects of the planktonic foraminiferal zonation of the Mediterranean Pliocene: Utrecht Micropaleontol. Bull., v. 28, pp. 1-159.

Sprovieri, R, Thunell, R, and Howell, M, 1986, Paleontological and geochemical analysis of three laminated sedimentary units of Late PlioceneEarly Pleistocene age from the Monte San Nicola section in Sicily: Riv. It. Paleont. Strat., v. 92, pp. 401-434.

Sprovieri, R, 1992, Mediterranean Pliocene biochronology: an high resolution record based on quantitative planktonic foraminifera distribution: Riv. It. Paleont. Strat., v. 98, pp. 61-100.

Domenico Rio is professor of micropaleontology and Head of the Department of Geology, Paleontoloygy and Geophysics of the University of Padova (Italy). He received his degree in geology at the University of Parma (Italy). Since 1996 he is chairman of the Subcommission on Neogene Stratigraphy. In February-April 1997 he has been co-chief scientist of ODP Leg 172 (North Atlantic Sediment Drifts). For many years he has been working on calcareous nannofossil paleontology, Mediterranean Neogene stratigraphy and Northern Apennines geology. His present research topics are the mid Brunhes climatic variability on the millenial time scale and the interactions of climate, tectonics and eustasy in shaping the Miocene and Pleistocene marine stratigraphic records of Italy.
Sprovieri, R, 1993, Pliocene-early Pleistocene Astronomically forced planktonic foraminifera abundance fluctuations and chronology of Mediterranean calcareous plankton bio-events: Riv. It. Paleont. Strat., v. 99, pp. $371-414$.

Verhallen, P J J M, 1987, Early development of Bulimina marginata in relation to paleoenvironmental changes in the Mediterranean: Proc. Ned. Akad. Wet., v. 90, pp. 161-180.

Zagwijn, W H, 1974, The Pliocene-Pleistocene boundary in western and southern Europe: Boreas, v. 3, pp. 75-97.

Zijderveld, J D A, Hilgen, F J, Langereis, C G, Verhallen, P J J M, and Zachariasse, W J, 1991, Integrated magnetostratigraphy and biostratigraphy of the upper Pliocene-lower Pleistocene from the Monte Singa and Crotone areas in Calabria (Italy): Earth and Planet. Science Letters, v. 107, pp. 697-714.

Davide Castradori is stratigrapher at the Agip's Laboratories in San Donato Milanese (Italy) and Secretary of the Subcommission on Neogene Stratigraphy. He made a Ph. D. at the University of Milan on the biostratigraphy and paleoceanography of the Quaternary in the eastern Mediterranean. His current field of study is nannofossil biostratigraphy of Cretaceous to Pleistocene sediments, with particular interest in the architecture of the Neogene biostratigraphic and chronostratigraphic framework.

Enrico Di Stefano is researcher at the Palermo University (Italy). He extensively works on NeogenePleistocene calcareous nannofossil assemblages, within research projects focusing on the biostratigrpahy, chronostratigraphy and paleoecology of the MiocenePleistocene Mediterranean sediments.

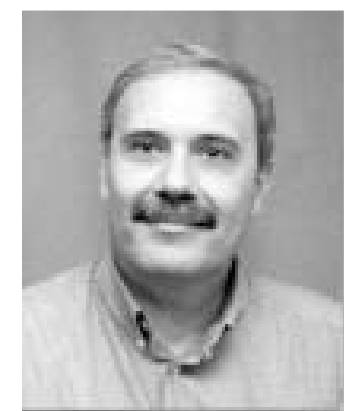

